\title{
PON-1, Possible Biomarker for Diagnosis But Also for Risk in Diastolic Dysfunction with Preserved Ejection Fraction
}

\begin{abstract}
BOGDAN IOAN COCULESCU, TUDOR HARSOVESCU, IOAN SORIN TUDORACHE*, GHEORGHE MANOLE
Titu Maiorescu University Bucharest, Faculty of Medicine, 22 Dambovnicului Str., Bucharest, Romania

The determined values of paraoxonase-1 serum concentration in 91 patients with cardiac insufficiency with a preserved ejection fraction with etiology of ischemic cardiopathy showed that this as an antioxidant enzyme may be accepted as a diagnostic biomarker, the assessment of the response to therapy, but also risk in this condition. Reporting circulating values of isozyme to the sex of patients revealed a very good correlation for males, which would confer PON1 specificity of sex to such a condition.
\end{abstract}

Keywords: heart failure with conserved systolic flow / diastolic dysfunction, ROS / RNS, paraoxonase-1 (PON1), diagnostic biomarker, respectively.

Currently, one of the major medical themes researched is the identification in various diseases of new molecular markers (markers) that allow the prognosis to be established, but also the response to a certain established therapy (prediction biomarkers). Extending the life of individuals and increasing the frequency of heart failure from $1-2 \%$ in the adult population, regardless of age, to 10 $12 \%$ in the over-70s, explains the interest in the world to identify itself in this affection, regardless of etiology, of biomarkers, to provide the possibility of complex evaluation of the condition.

The necessity of identifying such biomarkers that allows both the early evaluation of heart failure and the optimization of treatment to delay the occurrence of the irreducible form is also imposed by the objective of minimizing the consequences such as the significant deterioration of the quality of life, medical and social issues, etc.

The research object of this study is based on the fact that of the two clinical forms of heart failure (with a preserved ejection fraction, respectively reduced), about half are cases with conserved systolic flow, where the clinical symptoms are unspecific, hinders positive diagnosis and delays the establishment of appropriate therapy [1] .

There are, therefore, additional motivations fullyjustifying the interest of research to identify molecules that allow an early diagnosis of myocardial inotropic deficit. Although the pathogenesis of this form of cardiac insufficiency is relatively uncommon, the hypothesis of the existence of a diastolic dysfunction materialized by the devaluation of isovolumetric ventricular relaxation and the reduction of left ventricular compliance is universally accepted. [2-4]. For medical practice, identifying possible circulating biomarkers that by association with data provided by echocardiography could be complex / marker associations that would also allow a positive diagnosis to be certain criteria for dynamic evaluation of heart failure, in particular for the current study for myocardial diastolic dysfunction.

\section{Experimental part}

Material and method

Although in current medical practice they are admitted as biomarkers characterized by conserved conserved systolic blood flow, natriuretic peptide type B (BNP) and N- terminal Pro-BNP (Nt-proBNP), we have investigated whether paraoxonase -1 may be accepted as a diagnostic biomarker, possibly with a role in establishing prognosis and risk. For this purpose, we constituted a study group composed of 91 patients with heartfailure with a preserved ejection fraction, which presented the etiology of the myocardial inotropic deficiency the existence of only an ischemic heart disease (fig. 1).

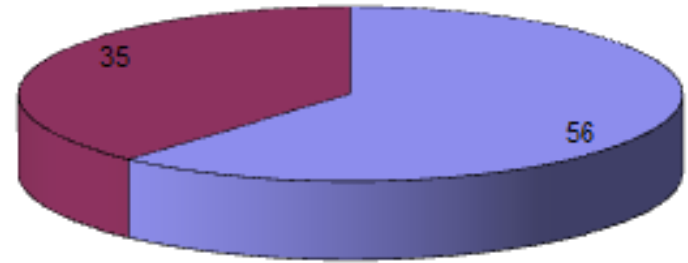

Fig. 1. The composition of the study group in relation to the sex of the patients

Legend: - Women=35 n $\mathrm{Men}=56$

In the studied case, we estimate that age was excluded as a factor of influence in the interpretation of the significance of serum values determined for PON 1 because the mean age of our group was 54.2 years and the sex of the patients was 55 for men and 53,38 for women. In support of this assertion, the literature from the literature shows that in the adult age, even after 65 years, the PON-1 serum concentration determinations are not varied.

In selecting the composition of the batch, other potential sources of PON-1 serum influence were also considered, excluding those who smoked or those who had hypolipidemic therapy at the time of the study $[4,6-10]$.

In order to have the whole group of patients under the same diet conditions and physical activity (other factors recognized to be able to influence PON-1 serum levels, patients were hospitalized for 2 weeks) [11-13].

The diagnosis was established following the electrocardiographic resting and echocardiography route. In the study group only patients who had only ischemic (subendocardic, subepicardial) changes in the rest of the electrocardiogram were not included in the patients with other associated electrocardiographic changes, such as the presence of lesion, necrosis (whether this and 
sequelae) or with disturbances of rhythm, except for the various forms of extrasistol.

Knowing that in low-systolic heart failure, the ejection fraction (FE) additionally contributes to the production of ROS / RNS by diminishing tissue perfusion and admitting that in the diastolic dysfunction with preservation of the ejection fraction, the rate of oxidant production is strictly localized at the myocardial level, as an expression of regional hypoxia, we proposed to study the variation in the serum concentration of PON1 in this category of patients.

For the serum-estradiol activity of PON1, the method used was the substrate, phenyl acetate. Determination of circulating values of PON1 was performed from serum of blood harvesting morning, jun, twice in 14 days, which is the length of hospitalization. On the basis of the values of the admissions, respectively from 14 days, the average concentration was then calculated for each of the two moments, thus obtaining two parameters, conventionally named:

- serum mean PON1 concentration at admission

- mean serum concentration of discharge PON1.

In order not to influence the results of the first determination of the isozyme, sampling was performed on the second day of hospitalization and outside the institution of therapy, which was later introduced. By imposing this requirement, we consider that we excluded the influence of physical effort, which at the time of admission varied in each patient, while a $24 \mathrm{~h}$ rest assured the work done.

The serum mean PON1 values calculated for the two harvesting moments (admission and discharge) allowed a third parameter to be obtained: the mean serum concentration of PON1 per batch, regardless of the time of harvest. It was used to calculate this last parameter - the mean serum concentration of PON-1, on the basis of which the results of the study were analyzed, we also justify it by the desire to have values of isozyme which would truthfully express its circulating level. Thus, we could analyze a serum concentration that expresses several determinations at different times, whose values are closer to reality.

Studying the dynamics of PON-1 values was possible:

- by interpreting those determined at admission to follow whether there is a correlation between the circulating activity of the isozyme and the severity of the contractile deficit, expressed by the ejection fraction value;

- by comparing the admission values with those determined at the end of the two-week treatment period, we obtained information on how serum PON1 correlates with the clinical development of cardiac insufficiency under the treatment set up according to the recommended therapeutic guide, the same for all patients.
- the circulating mean value of PON-1 based on the admission and discharge determinations gave us an opportunity to assess whether the obtained values correlate statistically significantly with the form of cardiac failure whose etiology is coronary atheromatosis.

In order to reduce costs, we did not constitute a control group, with normal clinical patients, to interpret the study data, comparing the values of the three determinations / calculations by reference to the normal circulating value recorded in the literature. We admitted as a risk level absent concentrations higher than $74 \mathrm{ng} / \mathrm{dL}$, and to assess the risk below the normal limit, graduating it:

a. values between $65-73 \mathrm{ng} / \mathrm{dL}$ : minimum risk;

b. circulating levels with 50-64 ng / dL: increased risk;

c. serum concentrations < $50 \mathrm{ng} / \mathrm{dL}$ : very high risk.

\section{Results and discussions}

Paraoxonase- 1 is one of the three isozymes synthesized in HDL-cholesterol-bound hepatocytes that develop an important antiatherosclerotic action due to its ability to easily detach from this complex to attach to LDLcholesterol molecules, preventing them oxidation [14-16].

However, the activity of a strong antiatherosclerotic protective factor is the expression of its capability to act in a catalytically variable manner, such as: phosphotriesterase, arylesterase, lactonase, peroxidase or as A 2phospholipase.

Reduction of the circulating level of paraoxonase allows the reactive species of oxygen (ROS) and nitrogen (RNS) interacting with the most diverse types / classes of biomolecules (polyunsaturated fatty acids, amino acids and proteins, nitrogenous bases) leading to the installation and augmentation of most cardiovascular diseases.

Among the objectives of the medical research regarding the identification of antioxidant (non-enzymatic and enzymatic) defense mechanisms is also the concern to identify circulating biomolecules that by their value become useful to the practice of cardiovascular diseases as biomarkers for the diagnosis, assessment and monitoring of patients. This study is part of these concerns because it follows whether its circulating concentrations of paraoxonase-1 serum can be accepted as a biomarker for: diagnosis of diastolic dysfunction, assessment of established therapy and implicitly of risk. In the case of biomarker admissibility, serum isozyme levels would be a real help since this form of cardiac failure evolves latently for a long time, medical practice lacking the possibility of early diagnosis [17-19].

1. In the group of 91 patients with the preserved ejection fraction, research into the incidence of serum average PON1 values under normal indicates that $96.7 \%$ of them exhibit a reduction in enzyme activity. The percentage is

\begin{tabular}{|c|c|c|c|c|c|c|}
\hline \multirow{4}{*}{$\begin{array}{l}\text { Selected areas of variation } \\
\text { of the calculated mean } \\
\text { value based on the two } \\
\text { determinations }\end{array}$} & \multicolumn{6}{|c|}{ sick number (91 / lot) } \\
\hline & \multirow{3}{*}{$\begin{array}{c}\text { no. } \\
\text { absent }\end{array}$} & \multirow{3}{*}{$\%$} & \multicolumn{4}{|c|}{ In relation to the sex of the sick } \\
\hline & & & \multicolumn{2}{|c|}{ men } & \multicolumn{2}{|c|}{ women } \\
\hline & & & $\begin{array}{c}\text { no. } \\
\text { absent }\end{array}$ & $\%$ & $\begin{array}{c}\text { no. } \\
\text { absent }\end{array}$ & $\%$ \\
\hline$<50 \mathrm{ng} / \mathrm{dl}$ & 69 & 75.8 & 40 & 44 & 29 & 31.7 \\
\hline $50-64 \mathrm{ng} / \mathrm{dl}$ & 12 & 13.1 & 9 & 9.9 & 3 & 3.3 \\
\hline $65-73 \mathrm{ng} / \mathrm{dl}$ & 7 & 7.8 & 5 & 5.49 & 2 & 2.2 \\
\hline $\begin{array}{l}\text { total cases with low values } \\
(<73 \mathrm{ng} / \mathrm{dl})\end{array}$ & 88 & 96.7 & 54 & 59.3 & 34 & 37.2 \\
\hline$>74 \mathrm{ng} / \mathrm{dl}$ & 3 & 3.2 & 2 & 2.2 & 1 & 1.1 \\
\hline No. Sick in lot & 91 & 100 & 56 & 61.5 & 35 & 38.4 \\
\hline
\end{tabular}

Table 1

DISTRIBUTION OF THE CONSTITUENT CASES OF THE GROUP, DEPENDING ON THE SEX AND MEAN SERUM ACTIVITY OF PON1 
valid when the serum value of PON1 is determined as the mean resulting from the admission and discharge determinations (table 1). The resulting value allows us to formulate that in the cases of heart failure with conserved systolic flow, the reduction in serum concentrations of PON1 occurs in nineteen of twenty cases, which statistically gives determinations of this type of disease biomarker specificity.

An argument in the same sense is the fact that in this batch, the majority of cases have significant decreases in serum enzyme activity $(<50 \mathrm{mg} / \mathrm{mL}: 75.8 \%$, the equivalent of 3 out of 4 patients) (table 1 ).

\begin{tabular}{|c|c|c|c|c|c|c|c|c|}
\hline \multirow{5}{*}{$\begin{array}{l}\text { The selected areas for the } \\
\text { variation of the } \\
\text { calculated mean value } \\
\text { based on the two } \\
\text { determinations }\end{array}$} & \multicolumn{8}{|c|}{ sick number } \\
\hline & \multicolumn{2}{|c|}{ lot $(n=91)$} & \multicolumn{6}{|c|}{ subgroup of male patients ( $n=56$ ) } \\
\hline & \multirow{2}{*}{\multicolumn{2}{|c|}{$\begin{array}{l}\text { based on the mean } \\
\text { concentration of } \\
\text { PON1, indifferent } \\
\text { to the dosing } \\
\text { moment }\end{array}$}} & \multicolumn{6}{|c|}{$\begin{array}{c}\text { depending on the mean concentration of PON1 } \\
\text { determined }\end{array}$} \\
\hline & & & \multicolumn{2}{|c|}{$\begin{array}{l}\text { irrespective of } \\
\text { the dosing time }\end{array}$} & \multicolumn{2}{|c|}{ at admission } & \multicolumn{2}{|c|}{ at discharge } \\
\hline & $\begin{array}{l}\text { nr. } \\
\mathrm{abs}\end{array}$ & $\%$ & $\begin{array}{l}\mathrm{nr} \text {. } \\
\mathrm{abs}\end{array}$ & $\%$ & $\begin{array}{l}\text { nr. } \\
\text { abs }\end{array}$ & $\%$ & $\begin{array}{l}\text { nr. } \\
\text { abs }\end{array}$ & $\%$ \\
\hline$<50 \mathrm{ng} / \mathrm{dl}$ & 69 & 75.8 & 40 & 44 & 42 & 75 & 38 & 67.8 \\
\hline $50-64 \mathrm{ng} / \mathrm{dl}$ & 12 & $\begin{array}{c}1 \\
3.1\end{array}$ & 9 & 9.9 & 10 & 17.8 & 8 & 14.28 \\
\hline $65-73 \mathrm{ng} / \mathrm{dl}$ & 7 & 7.8 & 5 & 5.49 & 5 & 8.9 & 5 & 8.9 \\
\hline $\begin{array}{l}\text { total cases with low } \\
\text { values }(\leftarrow 73 \mathrm{ng} / \mathrm{dl})\end{array}$ & 88 & 96.7 & 54 & 59.3 & 57 & 92.8 & 51 & 90.18 \\
\hline$>74 \mathrm{ng} / \mathrm{dl}$ & 3 & 3.2 & 2 & 2.2 & 2 & 3.57 & 2 & 3.57 \\
\hline No. Sick in lot & 91 & 100 & 56 & 61.5 & 59 & 96.37 & 53 & 93.75 \\
\hline
\end{tabular}

\begin{tabular}{|c|c|c|c|c|c|c|c|c|}
\hline \multirow{5}{*}{$\begin{array}{l}\text { The selected areas for the } \\
\text { variation of the calculated } \\
\text { mean value based on the } \\
\text { two determinations }\end{array}$} & \multicolumn{8}{|c|}{ sick number } \\
\hline & \multicolumn{2}{|c|}{ lot $(n=91)$} & \multicolumn{6}{|c|}{ subgroup of female patients ( $\mathrm{n}=56$ ) } \\
\hline & \multirow{2}{*}{\multicolumn{2}{|c|}{$\begin{array}{l}\text { based on the mean } \\
\text { concentration of } \\
\text { PON1, indifferent } \\
\text { to the dosing } \\
\text { moment }\end{array}$}} & \multicolumn{6}{|c|}{$\begin{array}{l}\text { depending on the mean concentration of PON1 } \\
\text { determined }\end{array}$} \\
\hline & & & \multicolumn{2}{|c|}{$\begin{array}{l}\text { irrespective of } \\
\text { the dosing time }\end{array}$} & \multicolumn{2}{|c|}{ at admission } & \multicolumn{2}{|c|}{ at discharge } \\
\hline & $\begin{array}{l}\text { nr. } \\
\text { abs }\end{array}$ & $\%$ & $\begin{array}{l}\mathrm{nr} \\
\mathrm{abs}\end{array}$ & $\%$ & $\begin{array}{l}\mathrm{nr} . \\
\mathrm{abs}\end{array}$ & $\%$ & $\begin{array}{l}\mathrm{nr} . \\
\mathrm{abs}\end{array}$ & $\%$ \\
\hline$<50 \mathrm{ng} / \mathrm{dl}$ & 69 & 75.8 & 29 & 31.7 & 29 & 51.78 & 28 & 50 \\
\hline $50-64 \mathrm{ng} / \mathrm{dl}$ & 12 & 13.1 & 3 & 3.3 & 4 & 7.14 & 2 & 3.57 \\
\hline $65-73 \mathrm{ng} / \mathrm{dl}$ & 7 & 7.8 & 2 & 2.2 & 2 & 3.57 & 2 & 3.57 \\
\hline $\begin{array}{l}\text { total cases with low } \\
\text { values }(<73 \mathrm{ng} / \mathrm{dl})\end{array}$ & 88 & 96.7 & 34 & 37.2 & 34 & 62.49 & 32 & 57.14 \\
\hline$>74 \mathrm{ng} / \mathrm{dl}$ & 3 & 3.2 & 1 & 1.1 & 1 & 1.78 & 1 & 1.78 \\
\hline No. Sick in lot & 91 & 100 & 35 & 38.4 & 35 & 64.27 & 33 & 58.92 \\
\hline
\end{tabular}

CASES IN RELATION TO THE MEAN SERUM ACTIVITY OF PON1 DETERMINED

Table 3

DISTRIBUTION OF CASES IN THE FEMALE SUBLOT IN TERMS OF MEAN SERUM ACTIVITY OF PON1 DETERMINED 
3. The data recorded in table 1 show that among the patients with heart failure with conserved systolic flow due to chronic ischemic cardiopathy, the serum enzyme significantly reduced ( $<50 \mathrm{ng} / \mathrm{dL}$ ), also prevalent in males:

40 cases of men $/ 29$ women cases $=44 \% / 31.7 \%$

Thus, of course, two male patients with conserved debut diastolic heart disease certainly have a very low serum concentration of paraoxonase-1; comparatively, only one in three in the sublot affiliates a significantly reduced circulating level for paraoxonase-1 isozyme.

4. Moderate reductions in serum PON1 levels (50-64ng / $\mathrm{dL}$ ) in the study group had a much lower incidence, occurring three times more frequently in males:

9 patients $/ 3$ patients $=9.9 \% / 3.3 \%$

Corroboration of these results with the above-mentioned ones is based on a further argument that the circulating level of paraoxonase-1 can be accepted as a cardiac failure biomarker due to chronic myocardial ischaemia, which preserves the ejection fraction value, the parameter proving greater specificity for cases male.

From the data of our study, it follows that the reduced levels by at least one third compared to circulating normal are statistically significant for diastolic dysfunction with conserved systolic flow $[20,21]$.

\section{Conclusions}

Within the study group, the incidence of a reduction in the mean serum PON1 concentration based on the sex of the patients showed that six (59.3\%) of ten male patients suffering from ischemic heart failure who conserved the systolic volume had concentrations serum average of PON1 relevant to the existence of an evolutionary risk. By comparison, in the case of women suffering from the same condition, at most four out of ten develop low circulating levels for PON1. Based on this statistical argument, we assert that the determination of serum concentration of PON1 constitutes both a diagnostic marker, allowing early indication of conserved diastolic dysfunction and a risk assessment biomarker [22-24].

We support admissibility as a risk biomarker, because its physiologically developed protective lipid peroxidation enzyme when serum PON1 is reduced reduces the body's ability to reduce oxidative stress, indirectly accentuating atherosclerotic lesions, including those located coronary [25-26].

For daily medical practice, our study data allows us to admit that lowering serum PON1 levels by more than onethird of normal values is a certain high risk indicator, especially for male cases.

\section{References}

1. SENNI M., REDFIELD M. M. - Heart failure with preserved systolic function. A different natural history - J. Am. Coll. Cardiol. 2001;38:12771282

2. CHIRCU C. M., MANITIU I., TEODORU M., CALUTIU N., SUCEVEANU P. N. - Importanta Biomarkerilor in Manangementul Pacientilor cu insuficienta cardiaca cu fractie de ejectie preservata, pag.110,Site:www.doctorateposdru.ulbsibiu.ro

3. DE KEULENAER G. W., BRUTSAERT D. L. - Systolic and diastolic heart failure are overlapping phenotypes within the heart failure spectrum. Circulation. 2011,123, pag.:1996-2004;

4. DINCA V.G., DINCA A.L., CAPITANESCU C., MANOLE GH. Cardiomyocyte membrane pathogenetic mechanisms and biochemical-induced endothelial-coronare in chronic ischemic heart disease, International J ournal of Current Research, martie 2017, vol.9, Issue 03, pag. 48435-48439;
5. ILEA I., DUNCEA C., PARV A. - Paraoxonaza-implicatii in aterogeneza. Aspecte biochimice si genetice. Clujul Medical 2010 Vol. LXXXIII - nr. 1, pag:9-12;

6. AVIRAM M., ROSENBLAT M., BISGAIER C. L., NEWTON R. S., Atorvastatin and gemfibrozil metabolites, but not the parent drugs, are potent antioxidants against lipoprotein oxidation. Atherosclerosis, 1998, 138, pag.: 271-280;

7. IVAN, M.V., GEORGESCU, M., APOSTOL, A., ALBULESCU, N., SERB, A.F., TATU, C.S., Rev. Chim. (Bucharest), 69, no. 7, 2018, p. 1616 8.JAMES R. W., LEVIEV I., RIGHETTI A. - Smoking is associated with reduced serum paraoxonase activity and concentration in patients with coronary artery disease. Circulation 2000, 101, pag.2252-2257; 9. DEAKIN S., LEVIEV I., GUEMIER S., JAMES R. W. - Simvastatin modulates expression of the PON1 gene and increases serum paraoxonase: a role for sterol regulatory element-binding protein-2. Arterioscler. Thromb. Vasc. Biol., 2003, 23, pag.:2083-2089;

10. DINCA V.G., MANOLE GH., COCHIOR D., DINCA A.L. Considerations regarding the biomarker value of circulant concentration of PON1 in patients with heart failure through chronic ischemic cardiomyopathy, Journal of Environmental Protection and Ecology (JEPE of B.En.A.), 2016, vol.17, no.4, pag.1563 -1574;

11. FERRE N., CAMPS J ., FERNANDEZ-BALLART J., ARIJA, MURPHY M. M., CERUELO S. - Regulation of serum paraoxonase activity by genetic, nutritional and lifestyle factors in the general population. Clin. Chem., 2003, 49, pag.:1491-1497;

12. DE ROOS N. M., SCHOUTEN E. G., SCHEEK L. M., VAN TOL A., KATAN M. B. - Replacement of dietary saturated fat with trans fat reduces serum paraoxonase activity in healthy men and women. (abstract).Metabolism, 2002, 51, pag.:1534-1537;

13. VAN DER GAAG M. S., VAN TOL A., SCHEEK L. M., JAMES R. W., URGEST R., SCHAAFSMA G. - Daily moderate alcohol consumption increases serum paraoxonase activity; a diet-controlled, randomized intervention study in middle-aged men. Atherosclerosis, 1999, 14, pag.:405-410;

14. SANDOR R., LEUCUA C. D., DRONCA E., NICULAE A., CRET V., SILAGHI C., SUCIU S. - Low Serum Paraoxonase-1 Lactonase and Arylesterase Activities in Obese Children and Adolescents, Revista Romana de Medicina de Laborator, 2015, Vol. 23, Nr. 4, pag.: 385-396; 15. LEUCUTA C. D., DUNCEA R., DRONCA M., LUPAN I., ILEA I. - The number of PON-1 mutant alleles, but not PON-1 phenotype, is associated with Gensini score of coronary damage., Revista Românã de Medicina de Laborator, 2013, Vol. 21, Nr. 4/4 , pag. 391-398;

16. BALAET C., COCULESCU B.I, MANOLE G., BALAET M., DINCA V.G. - Gamma-glutamyltransferase, possible novel biomarker in colon diverticulosis: a case-control study. J. Enzyme Inhib. Med. Chem. 2018, 33(1): 428-432.

17. BALAET C., COCULESCU B.I, BALAET M., MANOLE G., DINCA V.G. - Haemolytic anaemia and hepatocitolysis associated with hypermagnesaemia by repeated exposures to copper-calcium fungicides. J. Enzyme Inhib. Med. Chem. 2018, 33(1):184-189.

18. COCULESCU B.I, DINCA V.G., BALAET C., MANOLE G., BALAET M., STOCHECI C.M. - Myeloperoxidase, a possible biomarker for the early diagnosis of cardiac diastolic dysfunction with conserved ejection fraction. J Enzyme Inhib Med Chem. 2018, 33(1):1292-1298. 19.COCULESCU B.I, DINCA V.G., MANOLE G., PURCAREA V.L., STOCHECI C.M. - Serum concentration of hSCRP - possible marker for therapy evaluation in left ventricular dysfunction with preserved ejection fraction, Rev.Chim. (Bucharest), 69, no.10, 2018, p.2885-2890. 20.DINCA V.G., MANOLE GH., COCHIOR D., DINCA A.L.-Growth differential factor 15 (GDF-15), possible biomarker in heart failure Rev.Chim.(Bucharest), 68, no. 3, 2017, pg.631-634;

21. DINCA V.G., MANOLE GH., COCHIOR D., DINCA A.L. - Paraoxonase (PON1) possible biomarker for risk of heart failure - Rev.Chim. (Bucharest), 67, no. 5, May, 2016, pg.854-857;

22. CAPITANESCU C., MACOVEI OPRESCU A. M., IONITA D., DINCA G.V., TURCULET C., MANOLE GH., MACOVEI R. A. - Molecular process in streptokinase thrombolytic therapy - J ournal of Enzyme Inhibition 
and Medicinal Chemistry - ISSN: 1475-6366; Volume 31, 2016 - Issue 6; pg. 1411-1414;

23. DINCA G., SURDU T.V., IONESCU E.V., CATALIN G., MANOLE G., Rolul membranelor celulare in apoptoza cardiomiocitelor in cardiopatia ischemica cronica - Revista Medicina Moderna ISSN 12230472; 2013 Vol.XX-Nr.3,pg.158-160,

24. DINCA V.G., MANOLE GH., Organ failure as an expression of organ remodeling. Involvement of oxidative stress - J ournal of Medicine and Life ISSN 1844-122x; 2013; Volume 6, Issue 3, July-September; pg.240-243.
25. COCULESCU B.I., MANOLE GH., DINCA V.G., COCULESCU C.E., BERTEANU C., STOCHECI M.C. ,Osteopontin-a biomarker of disease, but also of stage stratification of the functional myocardial contractile deficit by chronic ischaemic heart disease - Journal of Enzyme Inhibition and Medicinal Chemistry - ISSN: 1475-6366; Volume 34, 2019 -Issue 1; pg. 783-788

26. COCULESCU B.I., MANOLE GH., HARSOVESCU T., TUDORACHE I.S., TONE M.B., DINCA A.L., Considerattions on the ethiopathogenesis of algae from the primary form of BMD - Rev.Chim. (Bucharest), pending publication

Manuscript received: 25.12 .2018 